THURSDAY, AUGUST 17, I876

\section{A PHYSICAL SCIENCE MUSEUM}

TANY of our readers will, no doubt, entertain the belief that the proposal to establish a Museum of Pure and Applied Science, to include what is known as the Patent Museum, recently laid before the Duke of Richmond and Gordon by the President of the Royal Society and other distinguished men of science, has been a thing of sudden growth. Some justification for such a belief may seem to be derived from the Loan Collection of Scientific Apparatus now being exhibited at South Kensington, and many of those who have witnessed its success would like to sce it developed into a permanent institution. No doubt, this Collection has helped to bring into practical shape the desire which for years many men of science in this country have possessed of seeing this country possessed of an institution similar to the Paris Conservatoire des Arts et Metiers, which desire has at last taken the form of the all but unanimous memorial on the subject which was recently presented to the LordPresident of the Council, and which we published in a recent number. But the truth is that this memorial is strictly in accordance with an official recommendation made to the Earl of Granville, then Lord-President of the Council, as far back as the year 1865 . At that time the Secretary of the Science and Art Department and Director of the South Kensington Museum, Mr. (now Sir) Henry Cole, along with the late Capt. Fowke, were instructed by the Lord-President to proceed to Paris and report upon the relations between the Conservatoire des Arts et Métiers and the French Patent system.

The results of this official visit to Paris were given in a report by Mr. Cole and Capt. Fowke to the Lord-President, which will be found in the "Twelfth Report of the Science and Art Department" (1865), and was laid before Parliament. As few of our readers can have access to this Report, and as those with whom the decision as to the memorial will rest, cannot be expected to know all that has been previously said and done in this matter, and as, moreover, the subject is one of prime importance to the country and to science, we believe we shall be doing good service by exhuming from this old blue-book the special Report to which we refer :-

REPORT ON THE CONSERVATOTRE DES ARTS ET Métiers and Brevets d'Invention.

To the Lord President of the Council. South Kensington Museum, Fanuary 1865. MY LORD, - In obedience to your Lordship's instructions that we should proceed to Paris and examine into the relations which exist between the Conservatoire des Arts et Métiers and system of French patents, we have prepared and have now the honour of submitting, the following report.

$\overline{1}$. The Conservatoire of late years, under the able direction of General Morin and M. Tresca, has become one of the most popular institutions in Paris.

2. This establishment, first created in 1788 , has passed through many phases of constitution and management. At the present time it has three predominant features: $(a)$, the public exhibition of machinery, manufactures, and models of an industrial and scientific nature; $(b)$, a scientific library open gratuitously to all; and $(c)_{2}$ courses of Vor XIV.-No. 355 gratuitous lectures given during the autumn and winter in the evening by the most eminent professors in France. These lectures are attended by several hundred persons. A prospectus of the courses for the present session is appended (p. 280).

3. Besides these three features, the Conservatoire is the repository for the Brevets d'Inventions and the models deposited with them, which have exceeded the age of I 5 years from the first issue of them. This connection of the institution with extinct Brevets d'Invention is a subordinate feature to its chief operations.

4. The Conservatoire consists of a series of ancient and modern buildings. The ancient, belonging to the abbey of St. Martin des Champs, date from A.D. 1060, and are highly interesting to the archæologist. They have been well adapted to the purposes of the establishment, especially the old refectory, now converted into the library.

5. The principal façade is now opened to the new Boulevard de Sevastopol, fronting a large square. Additional parts of the old monastic buildings of the convent of St. Martin are being restored and brought into use, whilst new buildings are being constructed to afford additional space. The ground already occupied by the establishment is $5^{\circ} 178$ acres (or $20,95^{\circ} 6$ métres carrés), and this is being extended to $6.55^{8}$ acres, or 26,540 métres carrés de terrain. The buildings themselves occupy at present 8,383 métres carrés, or $10,026.346$ square yards, which will be enlarged to $16,744^{\circ} 565$ square yards.

6. The laying out of the ground and the divisions into which the collection is arranged are shown by the accompanying plan (App. C).

7. The divisions are-machinery in motion, hydraulics in motion, agricultural implements, locomotives, horology, building models, \&c.

8. These plans show the position of the two chambers, the lower of which contains the specifications of Brevets $d^{\prime}$ Invention, whilst the upper contains the models. These chambers are on the opposite side of the court to the library, and have no connection with it. These rooms are about 60 feet long by 20 feet wide. The contents are very miscellaneous, and covered with dust, such as old hats, and woven fabrics, traps, tin ware, surgical appliances, and broken wooden models. It is not surprising that they are not considered of sufficient value or public interest to be kept with the general collection. They are never consulted. M. Tresca, the sous-directeur, has kindly answered some questions which we put to him (see p. 287). He shows that they do not influence the extent of the general collection of machinery, \&c., and their value to it is explained to be nothing.

9. On Thursdays and Sundays the galleries are open free, and are crowded. On other days, reserved for students, the principle of admitting the public by a moderate charge, as at South Kensington, has been adopted, and visitors pay one franc each.

Io. Four separate authorities throughout France are concerned in the issues and searches of Brevets d'Invention.

a. The Ministry of Finance.

b. The Ministry of Agriculture and Commerce.

c. The Prefecture of the Department.

d. The Conservatoive.

The necessary instructions, \&c., for obtaining a brevet are given in a paper appended (page 282). It will be cbserved that the instructions make no mention of models as any part of a Brevet d'Irvention, and, as M. Tresca shows, they are of no value whatever.

I I. In Paris all Brevets d'Invention are kept and registered. Those under 15 years of age are preserved in the Rue de Varennes, on the south side of the Seine; those above that age in the Conservatoire des Arts et Métiers on the north side, about two miles apart.

12. The steps necessary to be taken in Paris for ob- 
taining a Brevet d'Invention are as follows :-The applicant for a patent must first apply to No. 24, Rue de Mont Thabor. This is a subordinate bureau of the Ministère des Finances, not very readily found or publicly indicated. $\mathrm{He}$ passes through a gateway between the Café des Finances and a stable for remises. He ascends to the second stage up narrow stairs, dark and odorous. Here is the bureau for tine first stage of proceeding. He pays 5 francs, and obtains the necessary forms to be filled up; fills them up and pays 100 francs.

13. These forms being filled up, he takes them with the receipt to the Hôtel de Ville, and there he deposits his specification.

14. This specification is sent to a third bureau, which is on the opposite side of the Seine, No. 78, Rue de Varenne, the Ministère de l'Agriculture et du Commerce, and is also up two pairs of narrow dark stairs. Here the specifications are kept during I 5 years, whilst the patent lasts; after that period they are transferred with any models accidentally accompanying them to the Conservatoire des Aris et Metiers. The room for searches is about 60 feet long and 16 feet wide. The specifications are arranged in carton boxes on shelves. It is rather crowded. Anyone enters and searches in the printed catalogues and calls for the brevet without let or hindrance; but he is not permitted to make notes even in pencil. Copies must be ordered of the office at a given tariff, and if a copy of a drawing is required, he must bring his own draughtsman.

15. The catalogue of the specifications is printed, and may be bought at V. Bouchard Huzard, Rue d'Eperon, No. 5 .

16. It has been already pointed out that the law does not require that any models should be made, but some are sent. The officers kindly showed us what they possessed. We were conducted up back stairs into a little room about ro feet wide by 20 feet long. The flocr was covered with models unarranged, and very dusty. On a shelf were some models in tin, also very dusty. A model of a shoe was here, a candlestick there, \&c. The officer said that they were very rarely looked at, and the accuracy of the statement was fully borne out by the condition of the room. He said that ail the models in this small chamber were the products of some 20 years.

I7. These facts show that the Conservatoire des Arts et Métiers did not arise and is not at all dependent on any connection with models accidentally delivered with the Brevets d'Invention, which are not recognised by the French law. The Conservatoire is a great educational institution, teaching the general public through its exhibitions, and a special public through its lectures. It seems to us to afford an example which our own country might imitate with advantage generally as to scope and also in many of its details. - We have, \&c.

\section{(Signed) HENRY COLE,} FrancIS Fowke, Capt. R.E.

A map accompanies this Report which shows the buildings then occupied by the Conservatoire and those which it was proposed to build in addition. If the Commissioners of the 185 I Exhibition, to whose laudable scheme we recently referred, have not already consulted this map and the Report, we think they might do so with great advantage. There are many points in common between the scheme which they are considering and the plan which was then being carried out by the French Government, and which resulted in an institution that has been in working order for years, with, it is universally acknowledged, the best results to science and to France.

In the same Appendix M. Tresca furnishes answers to a number of questions with reference to the actual use made of the models of patents in the Patent Museum of
Paris. The information thus afforded we would recommend to the notice of the Treasury Commission which has for some time been cogitating as to what course to pursue with regard to our own Patent Museum. The analogy between the two cases is very complete, and it suggests that the best solution lies in a course similar to that which has been followed in France. From $M$. Tresca's answers we learn that in the Catalogue of Patents there were 7,300 entries of models, only Io of which are accompanied by specifications. While $I, 400$ specifications had been consulted during I 864 , not a single model had been examined or asked for, thus showing that the models were a practically useless part of the Patent Museum. M. Tresca states that the place of a model can be supplied by a drawing, leading to more complete, exact, and certain results, and thus avoiding useless expense. Their loss, therefore, would really be a gain to the Conservatoire; they cause, $M$. Tresca states, embarrassment by their compulsory preservation, the objects rarely representing the final idea of the inventor. They for the most part get destroyed by time without having been consulted by any one. Might not a somewhat similar report be made of our own Collection of "Patents"?

The same blue-book contains some valuable information with regard to the lectures which were then given in the Paris Conservatoire, which is worth consulting. Later and more complete information in this department may, however, be found in the appendix to the Report of the Duke of Devonshire's Commission. From what we have said, it will be seen that the idea of a Government Science Museum is by no means of recent growth, but that, on the contrary, it has taken many years to come to a practical issue ; and that, moreover, we have a ready-made example which has stood the test of years, and is now doing work of the highest practical value in the Paris Conservatoire des Arts et Métiers.

\section{COHN ON THE BIOLOGY OF PLANTS}

Beiträge zur Biologie der Pflanzen. Herausgegeben von Dr. Ferdinand Cohn. (Breslau, 1875.) Drittes Heft. THE third part of Cohn's "Beiträge," now before us, completes the first volume, and let us express the hope that we may have another volume before very long. Curiously, each of the three parts has been separately paged, an arrangement which renders it necessary to note the part as well as the page when the index is consulted. If we may judge from the size and price, each part has increased in importance, so that the third part has more papers and is nearly double the size of the first. In all the parts there have been papers of great interest and value, and those in the present part are in no way behind their predecessors. Dr. Cohn himself contributes three papers to the present part, Dr. J. Schrceter two, while Drs. L. Just, A. B. Frank, Richard Sadebeck, and Eduard Eidam, each one. The first paper is by Dr. Schrœter on the Development of certain Rust-Fungi. On Carex hirta, one of the Uredineæ was observed which Dr. Schrceter believes to be Puccinia caricis of De Candolle; and as he had reason to suspect that AEcidium urticce of Schum was only a stage in the life history of $P$. caricis, experiments were made to ascertain definitely whether $P$. caricis was hetercecious, and if so, whether Acidium 